Pak. j. sci. ind. res. Ser. A: phys. sci. 2019 62A(3) 146-156

\title{
Equilibrium and Thermodynamic Studies using Eco-Friendly Cola lepidota Seed Resins as Novel Adsorbents in the Removal of Pb (II) and Cd (II) Ions from Aqueous System
}

\author{
Armstrong Ehiedu Pat-Okunbor, Chidi Obi* and Millicent Uzoamaka Ibezim-Ezeani \\ ${ }^{a}$ Department of Pure and Industrial Chemistry, University of Port Harcourt, P. M. B. 5323, \\ Choba, Port Harcourt, Nigeria
}

(received April 25, 2018; revised October 24, 2018; accepted December 6, 2018)

\begin{abstract}
This study reveals the removal of $\mathrm{Pb}$ (II) and $\mathrm{Cd}$ (II) ions from aqueous system using unmodified Cola lepidota extract (UCE) and modified Cola lepidota extract resin (ECER). The modification was achieved by using ethanedioic acid and the adsorption process was carried out with respect to initial concentrations, temperature and $\mathrm{pH}$. Phytochemical analysis of the seeds was done by Gas Chromatography Mass Spectrometry (GC-MS). The zero point charge was evaluated and $\mathrm{Pb}$ (II) and $\mathrm{Cd}$ (II) ions equilibrium concentration was determined using Atomic Absorption Spectrophotometer (AAS). The GC-MS spectra suggested the seed contained 22 compounds. The zero point charge of UCE and ECER was found to be 4.0 and 7.0, respectively. Percentage removal of $\mathrm{Pb}$ (II) and $\mathrm{Cd}$ (II) ions onto ECER and UCE gave 89.35\%, $83.45 \%, 75.32 \%$ and $80.11 \%$, respectively. Optimal temperatures were $313 \mathrm{~K}$ and $303 \mathrm{~K}$ for $\mathrm{Pb}$ (II) and $\mathrm{Cd}$ (II) ions onto UCE, $303 \mathrm{~K}$ and $353 \mathrm{~K}$ for $\mathrm{Pb}$ (II) and Cd (II) ions onto ECER with $97.60 \%, 91.04 \%$, $97.44 \%$ and $90.22 \%$ metal ions removal. Optimal $\mathrm{pH}$ was 4.0 for $\mathrm{Pb}$ (II) ion onto UCE and ECER, 8.0 for Cd (II) ion onto UCE and 6.0 to 8.0 for Cd (II) ion onto ECER with $98.40 \%, 98.40 \%, 95.11 \%$ and 98.37\% removal. Langmuir, Freundlich, Temkin, Dubinin-Radushkevich and Redlich-Peterson isotherm model equations were tested and the result showed that Freundlich adsorption isotherm model equation fitted well with the removal of the metal ions onto UCE and ECER. Adsorption of $\mathrm{Pb}$ (II) ion onto UCE and ECER and Cd (II) ion onto UCE was exothermic with negative entropy while Cd (II) ion onto ECER was endothermic with positive entropy. The change in Gibbs free energy, $\Delta G^{\circ}$, was negative for all the metal ions. The unmodified Cola lepidota extract (UCE) and the ethanedoic acid Cola lepidota extract resin (ECER) can be recommended empirically as surfaces for heterogeneous reactions.
\end{abstract}

Keywords: Cola lepidota, seed resin, adsorption, equilibrium, heavy metals thermodynamics

\section{Introduction}

The increasing environmental pollution occasioned by unchecked human activities especially with heavy metal ion contamination in the environment is a major world health challenge which requires adequate attention (Gupta et al., 2015; Alok et al., 2010). Most automobiles in Nigeria emit lead which is a component additive in petroleum motor spirit from the exhaust pipes. Again, due to the current power shortage, an average family, institution and company or firm in Nigeria has at least one power generating plant which uses mainly leaded petroleum products. Along the roads, streets and markets are found milling machines, tyre-vulcanizing equipment, furniture making and spraying machines, car panelbiting and spraying equipment that are operated with leaded fuel which release lead contaminated fumes into the atmosphere in an uncontrollable manner.

*Author for correspondence; E-mail: zarasexcom@yahoo.com
Mining of minerals, petroleum exploration and production, iron and steel manufacturing industries largely contributed to the unprecedented pollution of the environment by heavy metals and metalloids such as iron, chromium, nickel, cadmium, mercury, lead, zinc, arsenic, etc. (Saleh et al., 2014; Giri and Singh, 2014). Menke et al. (2009) stated that exposure to cadmium is a major cause of cancer, prevalence of cardiovascular diseases in the masculine gender and mortality of both male and female at very high dose. Jurasovic et al. (2004) noted that cadmium and lead poisoning have been linked to cause endocrine infection which affect mostly men's sexual performance (Davies, 1987). The illegal mining of lead has caused the death of nothing less than four hundred (400) children in Zamfara State of Nigeria (Horsfall, 2011).

In recent times, there has been a conscious effort to use biological materials or agricultural produce and agricultural waste for bioremediation either in 
bioaccumulation or biosorption (Ahmaruzzaman and Gupta, 2011). The use of non-biological materials or waste such as active alumina, zeolites, silica gel, activated carbon, etc as adsorbents to remove heavy metal ions from contaminated source are not cost effective and environmentally friendly due to the generation of chemical sludge and other challenges.

Hence, the need for alternative approach in removing the metal ions from contaminated environment has become imperative (Gupta et al., 2014; Vinod et al., 2011). Hence, an invention arising from the challenges associated with the regular approach of heavy metal ions removal is the use of biological materials or/and agricultural wastes in the treatment of heavy metal ions in contaminated environment (Gupta et al., 2015).

Cola lepidota is an indigenous fruit found in West and Central African forests which is commonly called Monkey cola. It belongs to the family of Malvaceae and sub-family of Sterculioideae (Ogbu and Umeokechukwu, 2014). Cola lepidota has local names such as Achicha or Ochicha, Ohihia, Ndiya, Tuwo-biri, by the Ibos, Ikweres, Ibibios and the Hausas, respectively (IbezimEzeani et al., 2017). The nutritive values of Cola lepidota reveal that every $100 \mathrm{~g}$ of the mesocarp of Cola lepidota is composed of the following average contents: moisture content $82.60 \mathrm{~g}$; fibre ash $1.58 \mathrm{~g}$; energy value $55 \mathrm{kcal}$, fats $0.00 \mathrm{~g}$; carbohydrate $25.8 \mathrm{~g}$; crude protein $1.75 \mathrm{~g}$; vitamin C $11.28 \mathrm{mg}$; vitamin A $0.25 \mathrm{IU}$; phosphorus $0.09 \mathrm{mg}$; potassium $0.19 \mathrm{mg}$; calcium $0.42 \mathrm{mg}$; and magnesium $0.09 \mathrm{mg}$ (Ogbu et al., 2007).

There is little or no information on the application of Cola lepidota as sorbent for decontamination of trace metals, inorganic and organic materials from aqueous solutions, wastewaters and stimulated waters or heterogeneous surfaces for catalysis.

Therefore, this research was carried to determine the removal efficiency of the extract of Cola lepidota seed in the unmodified and modified forms for $\mathrm{Pb}$ (II) and Cd (II) ions from aqueous system.

\section{Materials and Methods}

Sample collection and pre-treatment. The Cola lepidota fruits were purchased from Sangana at mile 1 market, Port Harcourt, Nigeria, and identified at University of Port Harcourt Herbarium. They were washed properly using de-ionized water to remove potential particulate contaminants, then cut open and the seeds removed from the fruits. The seeds were cut into tiny sizes, sun-dried for twenty one days and milled using an electric grinder. The powdered Cola lepidota seeds were sieved at Geology Department of University of Port Harcourt using a set of Newark U.S.A standard test sieve (ASTM E-11 specification) until an average particle size of $150 \mu \mathrm{m}$ was obtained. It was then kept in an air-tight container made of polyethylene, and labeled as Unmodified Cola lepidota seed powder (UC). The following analytical grade chemicals were used for this research; propanone, ethanedioic acid, $n$-hexane, hydrochloric acid, sodium hydroxide, sodium thiosulphate pentahydrate, lead (II) nitrate, cadmium (II) chloride and iodine crystals.

Extraction and modification of Cola lepidota seed powder. The extraction was achieved using Soxhlet extractor and propanone as solvent. The extract paste was placed in a filter paper, firstly washed with $n$ hexane to remove the esters and residual propanone, and then finally washed with water to remove any left over n-hexane. The residue was dried at $323 \mathrm{~K}$ in an oven for $12 \mathrm{~h}$. A solid extract obtained was crushed into tiny particles and labelled Unmodified Cola lepidota Extract (UCE). Then, the extract (22.5 g) was weighed into $500 \mathrm{~mL}$ beaker and $150 \mathrm{~mL}$ of de-ionized water was added and stirred for $30 \mathrm{~min}$. Ethanedioic acid $(1.35 \mathrm{~g})$ was added while stirring for another $10 \mathrm{~min}$ at an increased temperature of $323 \mathrm{~K}$. Ethanedoic acid in this modification was used because it is very hydrophilic i.e. readily absorbs water and equally the acid is a good binder and chelating agent. After that $37.5 \mathrm{~mL}$ of iodine solution $(5 \% \mathrm{w} / \mathrm{v})$ was added, while still stirring at 323 $\mathrm{K}$ for another $80 \mathrm{~min}$ until the reaction was brought to an end by quenching techniques (rapid cooling to room temperature). Subsequently, $75 \mathrm{~mL}$ of saturated sodium thiosulphate pentahydrate was added and allowed to stand for $12 \mathrm{~h}$ at room temperature which gave rise to two layers. The organic layer was decanted into a filter paper, and washed with $500 \mathrm{~mL}$ of distilled water. The modified extract was dried in an oven at $323 \mathrm{~K}$ for 24 h. The resin prepared was labeled 'Ethanedioic Cola lepidota Extract Resin (ECER)'.

Metal ions stock solution preparation. A $1.6564 \mathrm{~g}$ sample of $\mathrm{Pb}\left(\mathrm{NO}_{3}\right)_{2}$ was weighed into $250 \mathrm{~mL}$ beaker, $100 \mathrm{~mL}$ of de-ionized water was added to dissolve the salt. The dissolved lead (II) nitrate was transferred into $1000 \mathrm{~mL}$ volumetric flask and made up to mark to prepare $1,036.219 \mathrm{mg} / \mathrm{L}$ of lead (Pb (II)) stock solution. 
$\mathrm{CdCl}_{2}(1.8336 \mathrm{~g})$ was dissolved in a $250 \mathrm{~mL}$ beaker and $100 \mathrm{~mL}$ of de-ionized water was added to dissolve the salt. The dissolved cadmium (II) chloride was transferred into $1000 \mathrm{~mL}$ volumetric flask and made up to mark to obtain $1,124.4 \mathrm{mg} / \mathrm{L}$ of cadmium (Cd (II)) stock solution.

Metal ions working solutions. Aliquots of the stock solution were transferred into various volumetric flasks, and made up to their respective marks to prepare different concentrations of the calibration standards and working solutions as required. This was achieved by applying the serial dilution equation 1 .

$$
\mathrm{C}_{1} \mathrm{~V}_{1}=\mathrm{C}_{2} \mathrm{~V}_{2}
$$
1

where:

$\mathrm{C}_{1}$ and $\mathrm{C}_{2}$ represent the concentration of stock and working solutions while $V_{1}$ and $V_{2}$ repesents the volume of stock and working solutions, respectively.

Characterization: Gas chromatography-mass spectrometery (GC-MS). UCE was subjected to GCMS analysis using Shimadzu GC-MS-QP 2010 to determine various components of the propanone extract and elucidate their possible structures.

Zero point charge (pHzPC) determination. The zero point charge UCE and ECER were determined by dispensing $0.01 \mathrm{M} \mathrm{NaCl}(50 \mathrm{~mL})$ solution into fourteen conical flasks $(100 \mathrm{~mL})$ and the $\mathrm{pH}$ of the solution adjusted in duplicates to 2.0, 4.0, 6.0, 8.0, 10.0, 11.0 using $0.1 \mathrm{M} \mathrm{NaOH}$ or $0.1 \mathrm{M} \mathrm{HCl}$. Some samples of UCE and ECER $(50 \mathrm{mg})$ were dispensed into each of the flask, corked properly, agitated mechanically (180 rpm) for $1 \mathrm{~h}$ and then allowed to stand for $48 \mathrm{~h}$ at room temperature. At the end, the mixtures were subjected to filtration using a filter paper. The $\mathrm{pH}$ of supernatant were measured and various changes in each $\mathrm{pH}$ value between initial $\left(\mathrm{pH}_{\mathrm{t}_{0}}\right)$ and final $\left(\mathrm{pH}_{\mathrm{t}_{1}}\right)$ obtained. Plots of changes between initial and final $\mathrm{pH}(\Delta \mathrm{pH})$ against initial $\mathrm{pH}$ were performed, the point(s) of intersection was taken as the zero point charge (Vieira et al., 2014).

Effect of initial concentration (IC) and adsorption studies at equilibrium. The adsorption on the surface of the UCE and ECER with Cd (II) and Pb (II) was carried out by adding $50 \mathrm{mg}$ of the resins into separate $100 \mathrm{~mL}$ conical flask containing $50 \mathrm{~mL}$ (each of 0.1 $\mathrm{mol} / \mathrm{L}-0.7 \mathrm{~mol} / \mathrm{L}$ ) of $\mathrm{Cd}$ (II) and $\mathrm{Pb}$ (II) ions, and adjusted the $\mathrm{pH}$ of UCE to 4.0, while ECER was adjusted to $\mathrm{pH}$ 7.0. The flasks were corked and the mixtures agitated mechanically (180 rpm) for $1 \mathrm{~h}$ and left to stand for $48 \mathrm{~h}$ at room temperature. The mixtures in the flasks were filtered through Whatmann filter paper after the shaking period. The supernatants were analyzed using Atomic Absorption Spectrophotometer (Buck scientificmodel 210 VGP) to quantify the metal ions at wavelengths of $228.9 \mathrm{~nm}$ for Cd (II) and $283.2 \mathrm{~nm}$ for $\mathrm{Pb}$ (II) ions. Thereafter, the removal of the ions at equilibrium and the adsorption capacity were calculated using equations 2 and 3 .

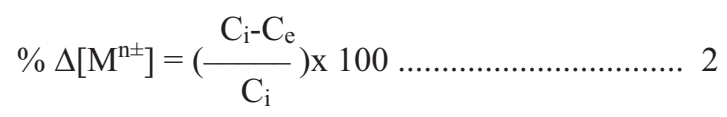

where:

$\% \Delta\left[\mathrm{M}^{\mathrm{n} \pm}\right]$ represent percentage metal ion removed, $\mathrm{C}_{\mathrm{i}}$ and $\mathrm{C}_{\mathrm{e}}$ are initial and equilibrium concentration in $\mathrm{mg} / \mathrm{L}$.

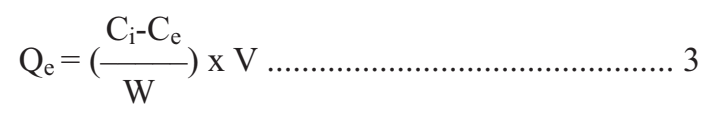

where:

$\mathrm{Q}_{\mathrm{e}}$ is the equilibrium amount adsorbed by the metal ions on the adsorbent (which is the ratio of adsorbate to sorbent in $\mathrm{mol} / \mathrm{g}$ ), $\mathrm{C}_{\mathrm{i}}$ and $\mathrm{C}_{\mathrm{e}}$ are initial and equilibrium concentration in $\mathrm{mol} / \mathrm{L}$ and $\mathrm{W}$ is weight of sorbent in grams and $\mathrm{V}$ is volume of adsorbate in litres.

Temperature studies. A $0.1 \mathrm{~mol} / \mathrm{L}$ solution of $50 \mathrm{~mL}$ each of $\mathrm{Pb}$ (II) and $\mathrm{Cd}$ (II) ions were added into several flasks containing $50 \mathrm{mg}$ of UCE and ECER at $\mathrm{pH}$ of 4.0. These were subjected to heating on Précis dig (6001197) JP Selecta water bath at the following temperatures; $303 \mathrm{~K}, 313 \mathrm{~K}, 323 \mathrm{~K}, 343 \mathrm{~K}$ and $353 \mathrm{~K}$ for 10 min each. Each sample mixture was then filtered at the end of the $10 \mathrm{~min}$ and the supernatant was analyzed to quantify the equilibrium concentration of the metal ion using Atomic Absorption Spectrophotometer. The percentage $S$ metal removal and equilibrium adsorption capacity was determined using equations 2 and 3 .

Thermodynamic parameters determination. The values of $\Delta \mathrm{S}^{0}, \Delta \mathrm{H}^{0}, \Delta \mathrm{G}^{0}$ were determined by the application of equations below at varying temperatures of $303 \mathrm{~K}, 313 \mathrm{~K}, 323 \mathrm{~K}, 343 \mathrm{~K}$ and $353 \mathrm{~K}$ (Crini and Badot, 2008).

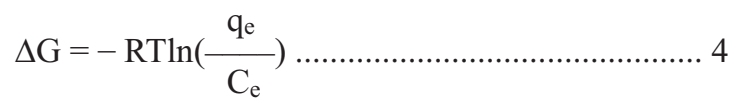




$$
\begin{aligned}
& \Delta \mathrm{G}^{\circ}=\Delta \mathrm{H}^{\circ}-\mathrm{T} \Delta \mathrm{S}^{\circ} \\
& \ln \left(\frac{\mathrm{q}_{\mathrm{e}}}{\mathrm{C}_{\mathrm{e}}}\right)=-\frac{\Delta \mathrm{H}}{\mathrm{RT}}+\frac{\Delta \mathrm{S}}{\mathrm{R}} \\
& \ln \mathrm{K}=\frac{\Delta \mathrm{S}^{\circ}}{\mathrm{R}}-\frac{\Delta \mathrm{H}^{\circ}}{\mathrm{RT}} \\
& \operatorname{InK}_{\mathrm{abs}}=-\frac{\mathrm{E}_{\mathrm{a}}}{\mathrm{RT}}+\ln \mathrm{K}_{\mathrm{a}} \\
& \Delta \mathrm{H}=-\frac{\mathrm{RT}_{1} \mathrm{~T}_{2}}{\mathrm{~T}_{2}-\mathrm{T}_{1}}\left(\ln \mathrm{C}_{\mathrm{i}}-\operatorname{In} \mathrm{C}_{\mathrm{e}}\right)
\end{aligned}
$$

where:

$\mathrm{K}_{\mathrm{abs}}$ and $\mathrm{K}_{\mathrm{a}}$ represent the absorption and dissociation constants.

Plot of $\ln \mathrm{K}_{\mathrm{abs}}$ versus $\frac{1}{\mathrm{~T}}$ is linear and from the slope and intercept: $\Delta \mathrm{S}^{\circ} \Delta \mathrm{H}^{\circ}, \Delta \mathrm{G}^{\circ}$ were calculated.

Effect of pH. A $50 \mathrm{mg}$ of UCE and ECER was weighed into several $150 \mathrm{~mL}$ flasks and $50 \mathrm{~mL}$ each of $0.1 \mathrm{~mol} / \mathrm{L}$ $\mathrm{Pb}$ (II) and Cd (II) ions was added to the flasks. The $\mathrm{pH}$ of the samples was adjusted using either $0.1 \mathrm{M}$ $\mathrm{NaOH}$ or $0.1 \mathrm{M} \mathrm{HCl}$ to the following $\mathrm{pH}$ of 2.0, 4.0, 6.0, 8.0, 10.0 and 11.0 for UCE and ECER, respectively. The flasks containing the mixtures were shaken mechanically $(180 \mathrm{rpm})$ for $1 \mathrm{~h}$. The samples were then filtered using Whatmann filter paper and the concentration of metal ions in the supernatant determined using Atomic Absorption Spectrophotometer. Equations 2 and 3 were used to evaluate the percentage ion removed and adsorption capacity, respectively.

\section{Results and Discussion}

Gas chromatography-mass spectrometer spectrum of UCE. The GC-MS spectrum of the UCE is presented in Fig. 1. The spectrum indicated the presence of twenty two compounds, which are presented in Table 1.

Zero point charge. Zero point charge $\left(\mathrm{pH}_{\mathrm{zpc}}\right)$ is an important characteristic of adsorbents. It is the $\mathrm{pH}$ at which the surface of adsorbent has neither positive nor negative charges.

Hence, at the zero point charge, the sorbent is said to be electrically neutral (Coskun et al., 2017). The zero point charge plots of UCE and ECER in Fig. 2 showed that the zero point charge of UCE was obtained at a $\mathrm{pH}$ of approximately 4.0 while that of ECER was obtained at a $\mathrm{pH}$ of approximately 7.0. This finding showed that the adsorption of $\mathrm{Pb}$ (II) and $\mathrm{Cd}$ (II) ions onto UCE and ECER surfaces were optimal at these $\mathrm{pH}$ values.

Effect of concentration on adsorption of $\mathrm{Pb}$ (II) and Cd (II) ions onto UCE and ECER. The effect of concentration on the adsorption of $\mathrm{Pb}$ (II) and $\mathrm{Cd}$ (II) ions onto UCE and ECER are presented in Fig. 3.

The results showed that there was a general increase in

\begin{tabular}{|c|c|c|}
\hline Name of compounds & $\begin{array}{l}\text { Molecular } \\
\text { formulas }\end{array}$ & $\begin{array}{l}\text { Percentage } \\
\text { assay( }(\%)\end{array}$ \\
\hline Octylacetylene (1-decyne) & $\mathrm{C}_{10} \mathrm{H}_{18}$ & 1.39 \\
\hline Glycerin (1, 2, 3- Propanetriol) & $\mathrm{C}_{3} \mathrm{H}_{8} \mathrm{O}_{3}$ & 7.14 \\
\hline Pelargic acid (Non-anoic acid) & $\mathrm{C}_{9} \mathrm{H}_{18} \mathrm{O}_{2}$ & 10.52 \\
\hline Undec-10-ynoic acid & $\mathrm{C}_{11} \mathrm{H}_{18} \mathrm{O}_{2}$ & 6.17 \\
\hline $\begin{array}{l}\text { Phenol, 3, 5-bis (1, } 1 \\
\text { dimethylethyl) }\end{array}$ & $\mathrm{C}_{14} \mathrm{H}_{22} \mathrm{O}$ & 0.36 \\
\hline 1-Pentadecene (Pentadec-1-ene) & $\mathrm{C}_{15} \mathrm{H}_{30}$ & 0.07 \\
\hline Ethyl ester (Decanoic acid) & $\mathrm{C}_{12} \mathrm{H}_{24} \mathrm{O}_{2}$ & 0.84 \\
\hline n-Butyl laurate (Dodecanoic acid) & $\mathrm{C}_{16} \mathrm{H}_{32} \mathrm{O}_{2}$ & 0.26 \\
\hline 1, 2-Benzenedicarboxylic & $\mathrm{C}_{16} \mathrm{H}_{22} \mathrm{O}_{4}$ & 0.38 \\
\hline $\begin{array}{l}\text { Methyl 14-Methyl Pentadecanoate } \\
\text { (Pentadecanoic acid) }\end{array}$ & $\mathrm{C}_{17} \mathrm{H}_{34} \mathrm{O}_{2}$ & 0.69 \\
\hline $\begin{array}{l}\text { Ethyl hexadecanoate } \\
\text { (Hexadecanoic acid) }\end{array}$ & $\mathrm{C}_{18} \mathrm{H}_{36} \mathrm{O}_{2}$ & 8.88 \\
\hline $\begin{array}{l}\text { Palmitic acid } \\
\text { (n-Hexadecanoic acid) }\end{array}$ & $\mathrm{C}_{16} \mathrm{H}_{32} \mathrm{O}_{2}$ & 0.42 \\
\hline $\begin{array}{l}\text { Linolelaidic acid }(9,12- \\
\text { Octadecadienoic acid) }\end{array}$ & $\mathrm{C}_{19} \mathrm{H}_{34} \mathrm{O}_{2}$ & 0.41 \\
\hline 10-Octadecenoic acid & $\mathrm{C}_{19} \mathrm{H}_{36} \mathrm{O}_{2}$ & 0.25 \\
\hline Cyclopentaneundecanoic acid & $\mathrm{C}_{17} \mathrm{H}_{32} \mathrm{O}_{2}$ & 0.31 \\
\hline $\begin{array}{l}\text { Linoleic acid (Ethyl cis, } \\
\text { cis-9, 12-Octadecadienoate) }\end{array}$ & $\mathrm{C}_{20} \mathrm{H}_{36} \mathrm{O}_{2}$ & 0.73 \\
\hline Spiro $[2,4]$ heptane & $\mathrm{C}_{10} \mathrm{H}_{16}$ & 43.30 \\
\hline $\begin{array}{l}\text { Grape seed oil }(9,12- \\
\text { Octadecadienoic acid }(Z, Z)\end{array}$ & $\mathrm{C}_{18} \mathrm{H}_{32} \mathrm{O}_{2}$ & 12.76 \\
\hline 9, 12-Tetradecadien-1-ol & $\mathrm{C}_{14} \mathrm{H}_{26} \mathrm{O}$ & 1.30 \\
\hline $\begin{array}{l}(\mathrm{Z}) 6,(\mathrm{Z}) 9- \\
\text { Pentadecadien-1-ol }\end{array}$ & $\mathrm{C}_{15} \mathrm{H}_{28} \mathrm{O}$ & 2.33 \\
\hline Di-n-octyl phthalate & $\mathrm{C}_{24} \mathrm{H}_{38} \mathrm{O}_{4}$ & 1.28 \\
\hline $\begin{array}{l}\text { Squalene }(2,6,10,14,18,22- \\
\text { Tetracosahexaene })\end{array}$ & $\mathrm{C}_{30} \mathrm{H}_{50}$ & 7.14 \\
\hline
\end{tabular}
the adsorption of adsorbates from the aqueous media by UCE and ECER. This could be attributed to the

Table 1. New compounds discovered from GC-MS analysis 
driving force which may be increasing due to the increasing initial concentrations of $\mathrm{Pb}$ (II) and $\mathrm{Cd}$ (II) ions (Coskun et al., 2017). The percentage removal of $\mathrm{Pb}$ (II) ion onto ECER was observed to be highest at $0.5 \mathrm{~mol} / \mathrm{L}$ and the sequence of removal followed as: $\mathrm{Pb}$ (II) ion $<\mathrm{Cd}$ (II) ion onto $\mathrm{UCE}<\mathrm{Cd}$ (II) ion $<\mathrm{Pb}$ (II) ion onto ECER.

Adsorption equilibrium isotherms. The experimental data were applied to the adsorption isotherm models in order to determine the nature of sorbent surface (either homogeneous or heterogeneous) and adsorption (physisorption, chemisorptions or ion exchange). The isotherm models tested include Langmuir, Freundlich, Temkin, Dubinin-Radushkevich and Redlich- Peterson.

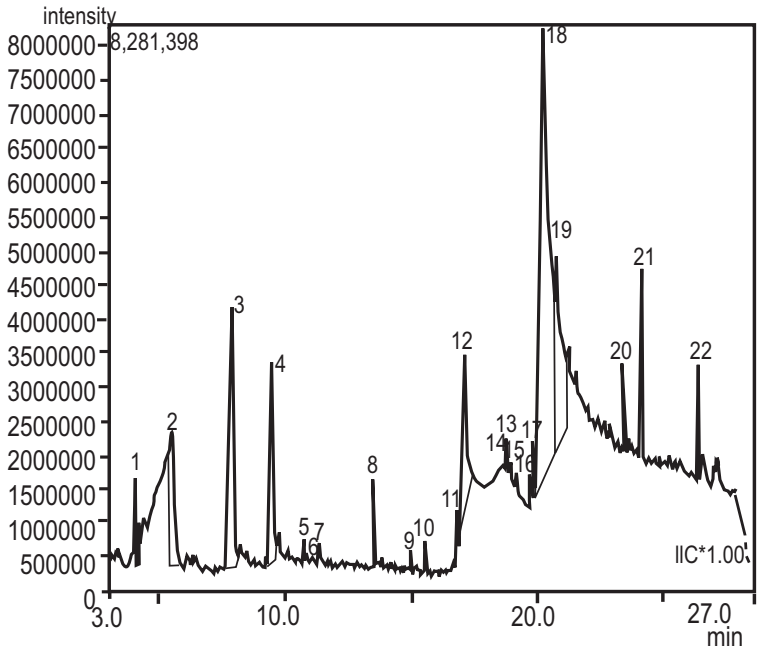

Fig. 1. GC-MS spectrum for UCE

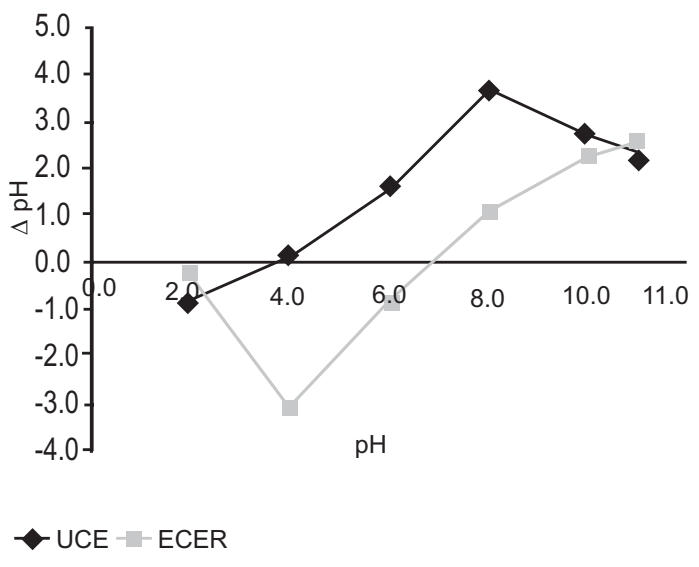

Fig. 2. Plots of $\Delta \mathrm{pH}$ against initial $\mathrm{pH}$ for $\mathrm{UCE}$ and ECER.

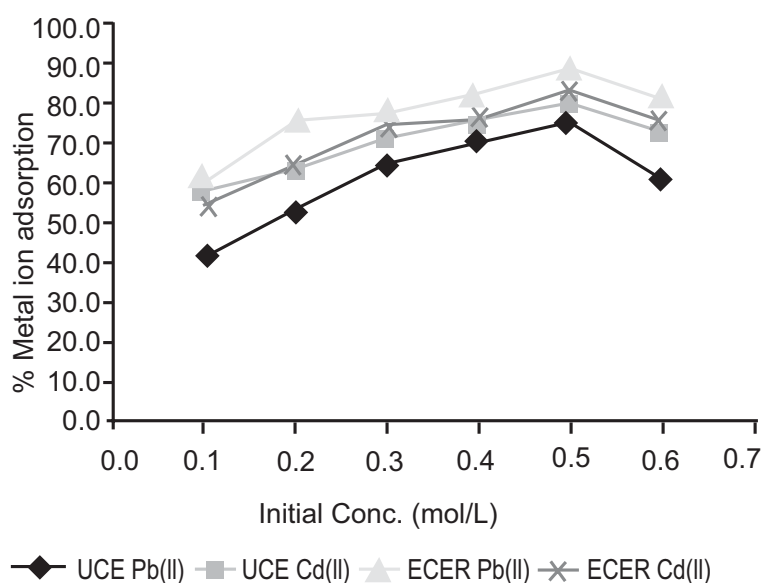

Fig. 3. Plots of metal ions removed (\%) against initial concentrations.

Langmuir isotherm model. The linearized Langmuir equation was given by Langmuir (1918) as:

$$
\frac{\mathrm{C}_{\mathrm{e}}}{\mathrm{Q}_{\mathrm{eq}}}=\frac{1}{\mathrm{~K}_{\mathrm{L}} \mathrm{Q}_{\mathrm{m}}}+\frac{\mathrm{C}_{\mathrm{e}}}{\mathrm{Q}_{\mathrm{m}}}
$$

where:

$\mathrm{C}_{\mathrm{e}}(\mathrm{mol} / / \mathrm{L})$ is the concentration of adsorbate at equilibrium, $\mathrm{K}_{\mathrm{L}}(\mathrm{L} / \mathrm{g})$ is the Langmuir isotherm constant related to sorption energy, $\mathrm{Q}_{\mathrm{eq}}(\mathrm{mol} / \mathrm{g})$ is the adsorption capacity at equilibrium, $\mathrm{Q}_{\mathrm{m}}(\mathrm{mol} / \mathrm{g})$ is the maximum coverage of the monolayer.

The data were investigated by plotting $\mathrm{C}_{\mathrm{e}} / \mathrm{eq}$ vs $\mathrm{C}_{\mathrm{e}}$ presented in Fig. 4. The result showed that adsorption

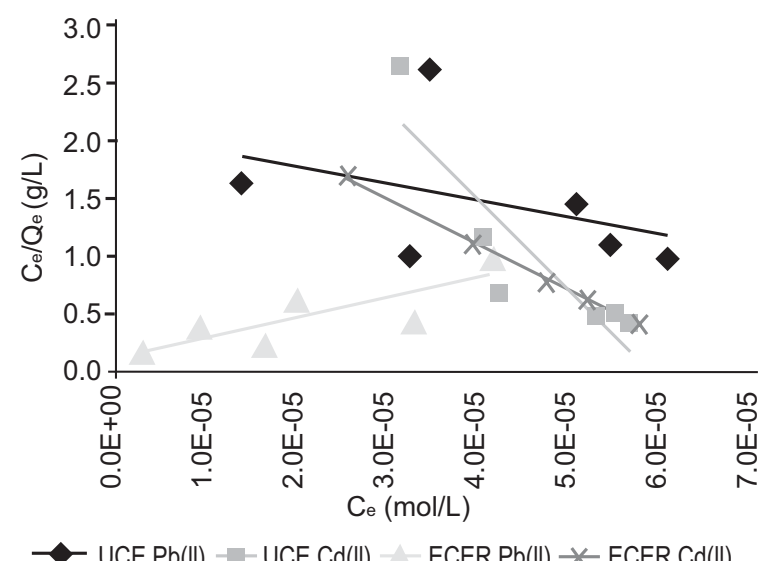

UCE Pb(II) - UCE Cd(II) - ECER Pb(II) * ECER Cd(II)

Fig. 4. Langmuir plots for UCE and ECER. 
of $\mathrm{Pb}$ (II) ion onto ECER had RL value of 0.03 and $\mathrm{R}^{2}$ value 0.696 which implied that the adsorption process was feasible and was best fitted into the Langmuir isotherm model. The adsorption of $\mathrm{Pb}$ (II) ion onto UCE, Cd (II) ion onto UCE and ECER all had better $\mathrm{R}^{2}$ values but negative $R L$ values suggesting that the adsorptions were not feasible. Hence, it can be inferred that the layer of UCE was homogeneous.

Freundlich isotherm model. The linearized form of the Freundlich equation was given as equation 11 (Freundlich, 1907) as:

$$
\log \mathrm{Q}_{\mathrm{eq}}=\log \mathrm{K}_{\mathrm{F}}+\frac{1}{\mathrm{n}} \log \mathrm{C}_{\mathrm{e}}
$$

where:

$\mathrm{Q}_{\mathrm{eq}}(\mathrm{mol} / \mathrm{g})$ is the adsorption capacity at equilibrium, $\mathrm{K}_{\mathrm{F}}(\mathrm{L} / \mathrm{g})$ the Freundlich constant, $\mathrm{C}_{\mathrm{e}}(\mathrm{mol} / / \mathrm{L})$ is the concentration of adsorbate at equilibrium, $\frac{1}{n}$ is the intensity of adsorption, $\mathrm{n}$ is the factor for heterogeneity which indicates the distribution of bonds and it is not dependent on the concentrations of adsorbents.

The investigation was carried out by the plot of $\log \mathrm{Q}_{\mathrm{eq}}$ vs $\log C_{e}$ presented in Fig. 5. The summary of the values of the constants and the $\mathrm{R}^{2}$ values is presented in Table 2 . The experimental data fitted very well for the adsorption process. The increasing order of fitness was as follows: $\mathrm{Cd}$ (II) ion onto $\mathrm{UCE}<\mathrm{Cd}$ (II) ion onto $\mathrm{ECER}<\mathrm{Pb}$ (II) ion onto $\mathrm{UCE}<\mathrm{Pb}$ (II) ion onto ECER. The $\mathrm{R}^{2}$ values showed that the adsorption of $\mathrm{Pb}$ (II) and $\mathrm{Cd}$ (II) ions onto UCE and ECER fitted very well into the Freundlich adsorption model and thus suggesting that the adsorbent surface were heterogeneous in nature and the adsorption of adsorbates onto the adsorbent was multilayered (Apemiye et al., 2017). This correlated with the kinetic plots obtained from Intra-particle and Boyd model. Also, adsorption of Cd (II) ion onto ECER had higher $\mathrm{R}^{2}$ value for Langmuir than for Freundlich adsorption isotherm model further suggesting that the modification of UCE to ECER increased the homogeneous nature of ECER's surface.

Temkin isotherm model. The Temkin equation used in this study was presented by Temkin (1934) and expressed as:

$$
\mathrm{Q}_{\mathrm{eq}}=\frac{\mathrm{RT}}{\mathrm{b}_{\mathrm{T}}} \ln \mathrm{K}_{\mathrm{T}}+\frac{\mathrm{RT}}{\mathrm{b}_{\mathrm{T}}} \ln \mathrm{C}_{\mathrm{e}}
$$

where:

$\mathrm{R}$ is the universal gas constants $(8.314 \mathrm{~J} / \mathrm{K} / \mathrm{mol}), \mathrm{T}$ is temperature in Kelvin (absolute temperature), KT is the Temkin binding equilibrium constant $(\mathrm{L} / \mathrm{mol})$ the values obtained from this corresponds to the highest possible binding energies, $\mathrm{b}_{\mathrm{T}}$ is related to the heat of adsorption.

The investigation was carried out by plotting $\mathrm{Q}_{\mathrm{eq}} \mathrm{vs} \ln$ $\mathrm{C}_{\mathrm{e}}$. and the $\mathrm{b}_{\mathrm{T}}$ and $\mathrm{K}_{\mathrm{T}}$ were determined from the slope and intercept of the curve (Fig. 6). The values were presented in Table 2. The result showed that the $\mathrm{R}^{2}$ values obtained where lesser than that obtained for Freundlich adsorption equilibrium isotherm. However, the $b_{T}$ and $K_{T}$ values obtained were high for all the adsorption processes.

Dubinin-Radushkevich (D-R) isotherm model. To resolve the adsorption mechanism, the deduced data were tested with the D-R adsorption isotherm (Dubinin, 1960). The equation is given as:

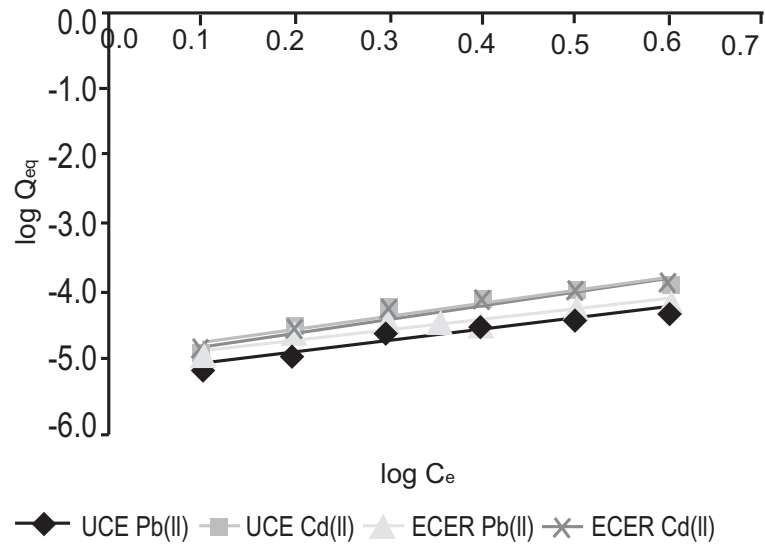

Fig. 5. Freundlich plots for UCE and ECER.

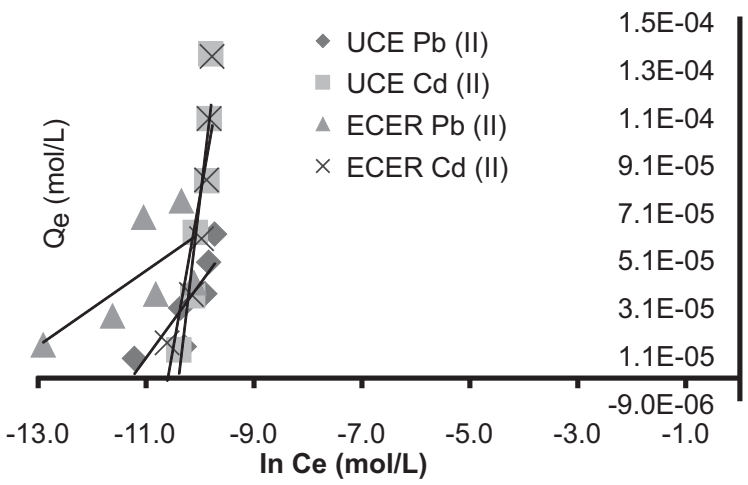

Fig. 6. Temkin plots for UCE and ECER. 
Table 2. Summary of isotherm equilibrium constants

\begin{tabular}{|c|c|c|c|}
\hline $\mathrm{UCE} \mathrm{Pb}$ (II) ion & UCE Cd (II) ion & ECER Pb (II) ion & ECER Cd (II) ion \\
\hline & \multicolumn{3}{|l|}{ Langmuir } \\
\hline $\mathrm{R}^{2}=0.171$ & 0.782 & 0.696 & 0.999 \\
\hline $\mathrm{K}_{\mathrm{L}}(\mathrm{g} / \mathrm{L})=-7306.06$ & -17142.83 & 160162.21 & -14899.82 \\
\hline $\mathrm{Q}_{\mathrm{m}}(\mathrm{mol} / \mathrm{g})=-0.000065$ & $-1.28 \mathrm{E}-05$ & $5.63 \mathrm{E}-05$ & $-2.51 \mathrm{E}-05$ \\
\hline \multirow[t]{2}{*}{$R_{L}=-3.1$} & -0.22 & 0.03 & -0.25 \\
\hline & \multicolumn{3}{|l|}{ Freundlich } \\
\hline $\mathrm{R}^{2}=0.943$ & 0.896 & 0.951 & 0.932 \\
\hline $1 / \mathrm{n}=0.174$ & 0.198 & 0.141 & 0.184 \\
\hline $\mathrm{n}=5.75$ & 5.05 & 7.09 & 5.43 \\
\hline \multirow[t]{2}{*}{$\mathrm{K}_{\mathrm{F}}(\mathrm{L} / \mathrm{g})=6.50 \mathrm{E}-6$} & $1.14 \mathrm{E}-5$ & $1.18 \mathrm{E}-5$ & $1.47 \mathrm{E}-5$ \\
\hline & \multicolumn{3}{|l|}{ Temkin } \\
\hline $\mathrm{R}^{2}=0.717$ & 0.895 & 0.457 & 0.777 \\
\hline $\mathrm{b}_{\mathrm{T}}(\mathrm{J} / \mathrm{mol})=83971400$ & 12595710 & 125957100 & 25191420 \\
\hline \multirow[t]{2}{*}{$\mathrm{K}_{\mathrm{T}}(\mathrm{L} / \mathrm{g})=22026.47$} & 22026.47 & 22026.47 & 1202604.28 \\
\hline & \multicolumn{3}{|c|}{ Dubinin-Radushkevich } \\
\hline $\mathrm{R}^{2}=0.816$ & 0.895 & 0.659 & 0.972 \\
\hline $\mathrm{Q}_{\mathrm{m}}(\mathrm{mol} / \mathrm{g})=6.50 \mathrm{E}-6$ & $6.50 \mathrm{E}-6$ & $1.18 \mathrm{E}-5$ & $1.31 \mathrm{E}-5$ \\
\hline $\mathrm{K}\left(\mathrm{mol}^{2} / \mathrm{kJ}^{2}\right)=0.17$ & 0.17 & 0.14 & 0.18 \\
\hline \multirow[t]{2}{*}{$\mathrm{E}(\mathrm{kJ} / \mathrm{mol})=1.74$} & 1.74 & 1.90 & 1.67 \\
\hline & \multicolumn{3}{|l|}{ Redlich-Peterson } \\
\hline $\mathrm{R}^{2}=0.174$ & 0.940 & 0.655 & 0.533 \\
\hline$g=-0.2768$ & -3.0043 & 0.4927 & -1.5997 \\
\hline $\mathrm{K}_{\mathrm{R}}(\mathrm{L} / \mathrm{g})-2.4967$ & -30.335 & 4.567 & -16.313 \\
\hline
\end{tabular}

$$
\log \mathrm{Q}_{\mathrm{eq}}=\log \mathrm{Q}_{\mathrm{m}} \mathrm{K} \varepsilon^{2}
$$

where:

$\mathrm{Q}_{\mathrm{eq}}$ and $\mathrm{Q}_{\mathrm{m}}$ represent adsorption capacity at equilibrium and D-R monolayer capacity $(\mathrm{mol} / \mathrm{g}$ ) respectively, $\varepsilon$ represents the Polanyi potential associated with the concentration at equilibrium $(\mathrm{J} / \mathrm{mol})$ and $\mathrm{K}$ describes the constant associated with energy of adsorption $(\mathrm{mol} / \mathrm{J})^{2}$.

The D-R adsorption equilibrium isotherm was investigated by plotting $\log \mathrm{Q}_{\text {eq }}$ vs. $\varepsilon^{2}$ (Fig. 7) and the values of $\log \mathrm{Q}_{\mathrm{eq}}$ and $\mathrm{K}$ were determined from the intercept and slope.

$\varepsilon$ was calculated using the equation.

$$
\varepsilon=\mathrm{RT} \ln \left(1+\frac{1}{\mathrm{C}_{\mathrm{e}}}\right)
$$

The mean free energy was calculated using the equation given as:

$\mathrm{E}=(2 \mathrm{~K})^{-0.5}$ 15
The D-R isotherm results presented in Table 2 showed that all the adsorption was by physisorption. However, the $\mathrm{Q}_{\mathrm{m}}$ was quite high as well as the $\mathrm{R}^{2}$ values except for the adsorption of $\mathrm{Pb}$ (II) ion onto ECER. The increasing order of the $\mathrm{R}^{2}$ values was as follows: $\mathrm{Pb}$ (II) ion onto ECER $<\mathrm{Pb}$ (II) ion onto $\mathrm{UCE}<\mathrm{Cd}$ (II) ion onto ECER $<\mathrm{Cd}$ (II) ion onto UCE.

In general, the D-R model suggest that the adsorption mechanism was by physical adsorption which also correlated with what was observed for the adsorption of $\mathrm{Pb}$ (II) and $\mathrm{Cd}$ (II) ions onto UCE, as well as $\mathrm{Pb}$ (II) ion onto ECER while investigating temperature effect on adsorption. The only exception was the adsorption of Cd (II) ion onto ECER. This suggests that all the adsorption process was a combination of physisorption and chemisorption but physisorption dominated all the processes since the chemical interactions between the adsorbates and adsorbent surface was weak.

Redlich-Peterson isotherm model. The RedlichPeterson adsorption equilibrium isotherm was a combination of the Langmuir and Freundlich equation (Redlich and Peterson, 1959). 


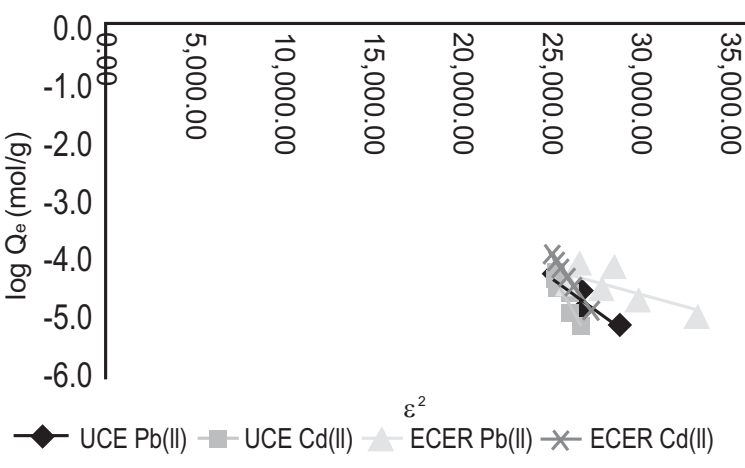

Fig. 7. Dubinin-Radushkevich plots for UCE and ECER.

$$
\begin{gathered}
\mathrm{Q}_{\mathrm{eq}}=\frac{\mathrm{Ce}}{1+\mathrm{K}_{\mathrm{R}} \mathrm{C}_{\mathrm{e}}^{\mathrm{g}}} \ldots \ldots \ldots \ldots \ldots \ldots \ldots \ldots \ldots \\
\ln \left(\frac{\mathrm{C}_{\mathrm{e}}}{\mathrm{Q}_{\mathrm{eq}}}\right)=\mathrm{g} \ln \mathrm{Ce}-\ln \mathrm{K}_{\mathrm{R}}
\end{gathered}
$$

where:

The constants $\mathrm{KR}(\mathrm{L} / \mathrm{g})$ and $\mathrm{a}_{\mathrm{R}}$ represent the RedlichPeterson (R-P) adsorption equilibrium isotherm constants, $g$ represents the exponent taking values between 1 and 0 , as g approaches 0 , Henry's law; and $\mathrm{g}=1$ changes the R-P equation into the Langmuir form.

The investigation was carried out by plotting $\ln \left(\frac{\mathrm{Ce}}{\mathrm{Qeq}}\right)$ vs $\ln \mathrm{C}_{\mathrm{e}}$ as shown in Fig. 8. The g values obtained for the adsorption process was negative except for $\mathrm{Pb}$ (II) ion onto ECER with a value of 0.493 and this further suggest that the active surfaces of adsorption of the $\mathrm{Pb}$ (II) ion onto ECER was a combination of heterogeneous (multilayer) and homogeneous (monolayer) surfaces probably due to the modification process. Also, the ' $\mathrm{g}$ ' value obtained for $\mathrm{Pb}$ (II) ion onto ECER also fell between 0 and 1 which also confirmed that the adsorption was favorable. The $\mathrm{R}^{2}$ values for Cd (II) ion onto UCE and ECER was high but still below that for Freundlich. Hence, this model was not the best fit for the adsorption process in this study.

Effect of temperature. The temperature studies on the adsorption of $\mathrm{Pb}$ (II) and $\mathrm{Cd}$ (II) ions onto the sorbents are presented in Fig. 9. Adsorption of $\mathrm{Pb}$ (II) ion onto UCE reached a maximum between $303 \mathrm{~K}$ to $313 \mathrm{~K}$ similar to what was reported by Seker et al. (2004), after which a further increase in temperatures above $313 \mathrm{~K}$ resulted in a decrease in the adsorption and percentage removal of adsorbates suggesting an endothermic process below $313 \mathrm{~K}$ and exothermic process above $313 \mathrm{~K}$.

Adsorption of $\mathrm{Pb}$ (II) and $\mathrm{Cd}$ (II) ions onto $\mathrm{UCE}$ and ECER decreased with increase in temperature suggesting that physisorption probably occurred (Ibezim-Ezeani et al., 2012). This observation may be due to an increasing weak interaction occurring between the adsorbates and the sorbent binding sites; the deformation of the active sites may also have occurred as a result of increased temperature leading to distortion of the sorbents structural arrangement (Saravanan et al., 2013). However, the adsorption of Cd (II) ion onto ECER and the percentage removal gradually increased as the temperature increased from $303 \mathrm{~K}$ to $353 \mathrm{~K}$ suggesting that the process was endothermic and probably chemisorption occured similar to what was reported

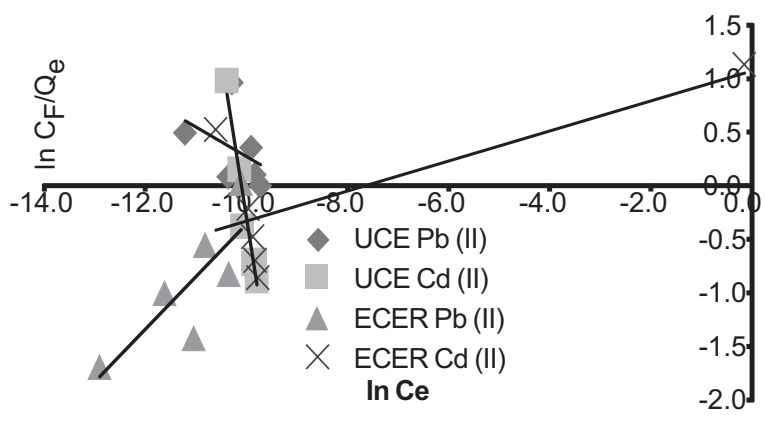

Fig. 8. Redlich-Peterson plots for UCE and ECER.

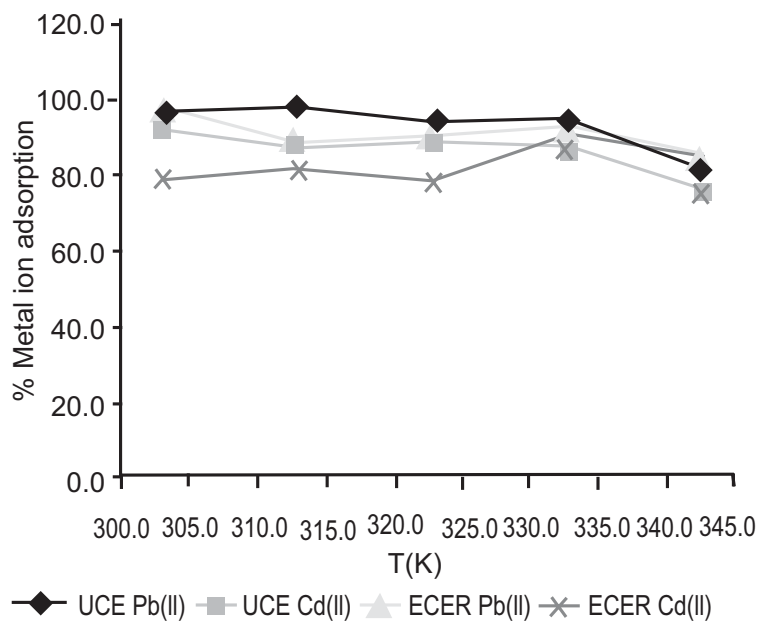

Fig. 9. Plots of metal ions removed (\%) against temperature $(\mathrm{K})$. 
by Nethaji et al. (2013). From the data generated, effect of temperature on adsorption and percentage removal of adsorbates from aqueous medium was not really pronounced (Coskun et al., 2017). Generally, the order of adsorption from aqueous medium at lower temperature was as follows: $\mathrm{Cd}$ (II) ion onto ECER $<\mathrm{Cd}$ (II) ion onto $\mathrm{UCE}<\mathrm{Pb}$ (II) ion onto $\mathrm{UCE}<\mathrm{Pb}$ (II) ion onto ECER while the increasing order of removal and adsorption of adsobates at higher temperature was as follows: $\mathrm{Cd}$ (II) ion onto $\mathrm{UCE}<\mathrm{Cd}$ (II) ion onto ECER $<\mathrm{Pb}$ (II) ion onto ECER $<\mathrm{Pb}$ (II) ion onto UCE.

Thermodynamic analysis. The thermodynamic parameters were presented in Table 3 while the Van't Hoff plot was shown in Fig. 10. The values obtained suggest that the adsorption of $\mathrm{Pb}$ (II) and $\mathrm{Cd}$ (II) ions onto UCE and $\mathrm{Pb}$ (II) ion onto ECER was exothermic while Cd (II) ion onto ECER was endothermic. The negative values of $\Delta \mathrm{S}^{\circ}$ also suggest that the degree of randomness for the adsorption of $\mathrm{Pb}$ (II) and $\mathrm{Cd}$ (II) ions onto $\mathrm{UCE}$ and $\mathrm{Pb}$ (II) ion onto ECER reduced while that of Cd (II) ion on ECER increased on the surfaces of the sorbents (Mohammadi et al., 2011). Also, the negative values of $\Delta \mathrm{G}^{\circ}$ suggest that the adsorption processes were spontaneous and feasible.

Effect of $\mathbf{p H}$. Adsorption process was greatly influenced by the $\mathrm{pH}$ of the medium (Coskun et al., 2017; Kalembkiewicz, 2016).

The $\mathrm{pH}$ analysis presented in Fig. 11 showed that at lower $\mathrm{pH}$, adsorption of $\mathrm{Pb}$ (II) and $\mathrm{Cd}$ (II) ions onto UCE and ECER were low which could be as a result of charge repulsion between the positively charged metal ions and hydrogen ions (Soco and Kalembkiewicz, 2016). However, at $\mathrm{pH} 4.0$, the adsorption and percentage removal of $\mathrm{Pb}$ (II) ion onto UCE was higher than for $\mathrm{Pb}$ (II) ion onto ECER. Also, the adsorption of Cd (II) ion onto ECER was higher than adsorption of Cd (II) ion onto UCE at 6.0 to 8.0. The $\mathrm{pH} 4.0$ for UCE adsorption coincided with the zero point charge of UCE. However, adsorption of $\mathrm{Pb}$ (II) ion onto UCE and ECER was the same and highest at $\mathrm{pH} 6.0$ to 7.0 coinciding

Table 3. Thermodynamic values for $\mathrm{Pb}$ (II) and $\mathrm{Cd}$ (II) ions onto UCE and ECER

\begin{tabular}{lllll}
\hline \hline Parameter & $\begin{array}{l}\text { UCE Pb } \\
\text { (II) ion }\end{array}$ & $\begin{array}{l}\text { UCE Cd } \\
\text { (II) ion }\end{array}$ & $\begin{array}{l}\text { UCER Pb } \\
\text { (II) ion }\end{array}$ & $\begin{array}{l}\text { UCER Cd } \\
\text { (II) ion }\end{array}$ \\
\hline$\Delta \mathrm{H}^{\circ}(\mathrm{kJ} / \mathrm{mol})$ & -11.201 & -14.633 & -20.671 & 10.613 \\
$\Delta \mathrm{S}^{\circ}(\mathrm{kJ} / \mathrm{mol})$ & $-9.69 \mathrm{E}-03$ & -0.029 & -0.043 & 0.047 \\
$\Delta \mathrm{G}^{\circ}(\mathrm{kJ} / \mathrm{mol})$ & -8.265 & -5.846 & -7.642 & -3.628 \\
\hline \hline
\end{tabular}

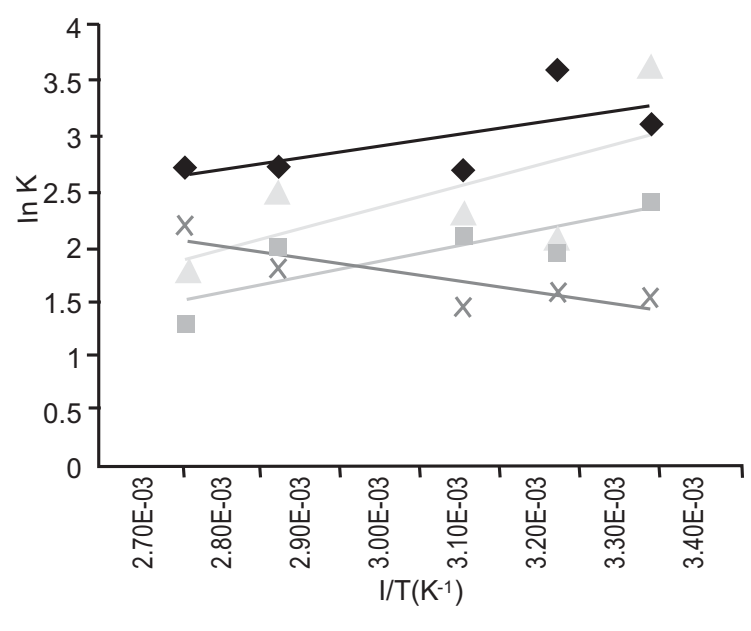

UCE Pb(II) - UCE Cd(II) - ECER Pb(II) $\star$ ECER Cd(II)

Fig. 10. Van't Hoff plots for UCE and ECER.

with the zero point charge of ECER suggesting that at zero point charge, there was little or no competition between the hydrogen ions and the metal ions for the adsorbents active binding sites as the $\mathrm{H}^{+}$on the adsorbents surfaces has been overshadowed by the $\mathrm{Pb}$ (II) ion. The decrease in the percentage metal ions removal from $\mathrm{pH} 8.0$ to 11.0 may also be as a result of the amphoteric nature of $\mathrm{Pb}(\mathrm{OH})_{2}$ thereby leading to precipitation of the slightly insoluble $\mathrm{Pb}(\mathrm{OH})_{4}$ (Soco and Kalembkiewicz, 2016). Thus, the high $\mathrm{pH}$ values must be avoided in this kind of metal ions removal. Soco and Kalembkiewicz (2016) also reported similar observation for $\mathrm{Cd}$ (II) ion and this could be attributed

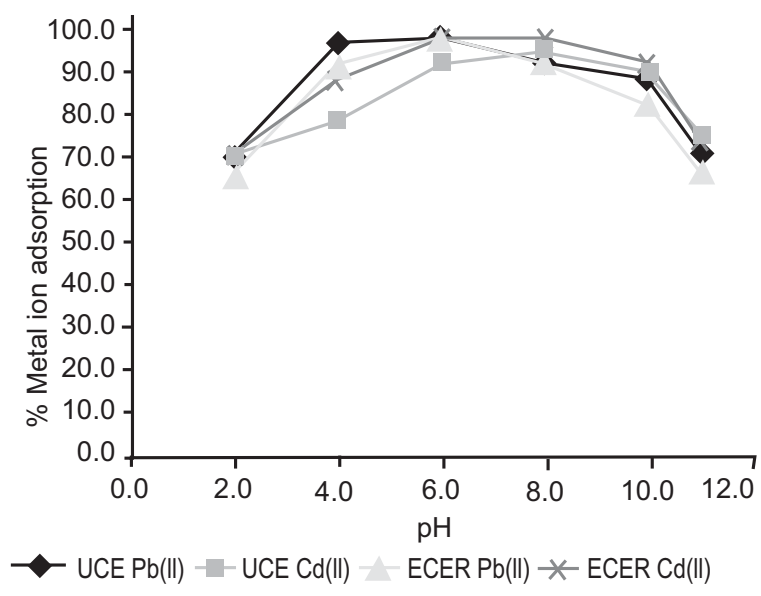

Fig. 11. Plots of metal ions removed (\%) against $\mathrm{pH}$. 
to the likely formation of $\mathrm{Cd}(\mathrm{OH})_{2}$ and $\mathrm{Cd}(\mathrm{OH})^{+}$since there was almost little or no competition from $\mathrm{H}^{+}$at $\mathrm{pH}$ 6.0 to 9.0 .

\section{Conclusion}

Cola lepidota seeds are composed of twenty two chemical compounds confirmed from the GC-MS phytochemical analysis. The modification of Cola lepidota seeds was successfully done using ethanedioic acid as the modifying agent. The resins of Cola lepidota in the unmodified and modified forms were very good, efficient and feasible adsorbents. All the adsorption process was mainly physisorption with mean free energy less than $8 \mathrm{~kJ} / \mathrm{mol}$. The adsorption process fitted well with the Freundlich adsorption isotherm model equation indicating that the resin had heterogeneous surface. The thermodynamic parameters showed that adsorption of $\mathrm{Pb}$ (II) and $\mathrm{Cd}$ (II) ions onto UCE and $\mathrm{Pb}$ (II) ion UCER was exothermic while the adsorption of Cd (II) ion onto ECER was endothermic and the standard entropy values for the adsorption of $\mathrm{Pb}$ (II) and $\mathrm{Cd}$ (II) ions onto $\mathrm{UCE}$ and $\mathrm{Pb}$ (II) ion on UCER was negative indicating that the degree of randomness reduced on the surfaces of the adsorbents while the adsorption of Cd (II) ion onto ECER was positive indicating that the degree of randomness increased on the surface of the adsorbent. The Gibbs free energy for the adsorption process was negative indicating that the adsorption process was reversible, spontaneous and feasible. The unmodified Cola lepidota recorded a higher percentage removal of $\mathrm{Pb}$ (II) ion onto UCE than onto ECER at $\mathrm{pH} 4.0$ while adsorption of $\mathrm{Cd}$ (II) ion onto ECER occurred at $\mathrm{pH}$ 6.0 to 8.0 and also recorded a higher percentage removal of Cd (II) ion onto ECER than UCE. However, for selective and quick removal of $\mathrm{Pb}$ (II) ion at $\mathrm{pH} 6.0$ in the presence of competing metal ions that can be removed below $\mathrm{pH}$ 6.0, the ECER is recommended the best option for the adsorption. The difference in the adsorption of Cd (II) ion onto UCE and ECER was more pronounced especially under the influence of $\mathrm{pH}$; hence $\mathrm{Cd}$ (II) ion onto ECER was significantly better than $\mathrm{Cd}$ (II) ion onto UCE at pH 6.0 to 8.0. However, $\mathrm{UCE}$ is best used in the adsorption of Cd (II) ion from aqueous medium at $\mathrm{pH}$ of 6.0 while above 6.0; ECER is a better option for the adsorption.

\section{Acknowledgement}

The authors wish to thank the National Research Institute for Chemical and Technology, Basawa, Zaria, Kaduana,
Chemistry Department Laboratory University of Benin, Multi-User Science Research and Chemical Engineering Laboratories, Ahmadu Bello University, Zaria for providing the laboratory facilities for the structural characterization of UCE and ECER. The helpful interpretation of GC-MS spectra by Dr. I. Orji is gratefully acknowledged.

Conflict of Interest. The authors declare no conflict of interest

\section{References}

Ahmaruzzaman, M., Gupta, V. K. 2011. Rice husk and its ash as low-cost adsorbents in water and waste water treatment. Industrial and Engineering Chemistry Research, 50: 13589-13613.

Alok, M., Jyoti, M., Arti, M., Gupta, V. K. 2010. Removal and recovery of chrysoidine $\mathrm{Y}$ from aqueous solutions by waste materials. Journal of Colloid and Inerface Science, 344: 497-507.

Apemiye, M. A., Obi, C., Okoye, I. P. 2017. Equilibrium dynamics of $\mathrm{m}-$ xylene removal from aqueous solution by organoclay. Iranian Journal of Sciecnce and Technology: Trans Science, doi.org/10.1007/ s40995-017-0422-7.

Coskun, A., Yildiz, A., Delibas, A. 2017. Removal of methylene blue using fast sucking adsorbent. Journal of Materials and Environmental Sciences, 8: 398-409.

Crini, G., Badot, P. M. 2008. Application of chitosan, a natural aminopolysaccharide, for dye removal from aqueous solutions by adsorption processes using batch studies: a review of recent literature. Progress in Polymer Science, 33: 399-447.

Davies, K.J. 1987. Prolein damage and degradation by oxygen radicals. Journal of Biological Chemistry, 262: 9895-9901.

Dubinin, M. M. 1960. The potential theory of adsorption of gases and vapors for adsorbents with energetically non-uniform surface. Chemistry Review, 60: 235266.

Freundlich, H. M. F. 1907. Ueber die adsorption in Loesungen. Z. Journal of Physical Chemistry, 57: 385-470.

Giri, S., Singh, A. K. 2014. Risk assessment, statistical source identification and seasonal fluctuation of dissolved metals in the Subarnarekha River, India. Journal of Hazardous Materials, 265: 305-314. 
Gupta, V. K., Atar, N., Yola, M. L., Ustundag, Z., Uzun, L. 2014. A novel magnetic Fe@Au core-shell nanoparticles anchored grapheme oxide recyclable nanocatalyst for the reduction of nitrophenol compounds. Water Research, 48: 210-217.

Gupta, V. K., Nayak, A., Agarwal, S. 2015. Bioadsorbents for remediation of heavy metals; Current status and their future prospects. Environmental Engineering Research, 20: 001-018.

Horsfall, M. Jr. 2011. Chemistry and heavy metals are Janus-faced. An Inaugural Lecture Series no. $81^{\text {st }}$ at Department of Pure and Industrial Chemistry, University of Port Harcourt. pp 11-12.

Ibezim-Ezeani, M. U., Okoye, F. A., Akaranta, O. 2012. Equilibrium studies of some metal ions onto modified orange mesocarp extract in aqueous solution. American Chemical Science, 2: 25-37.

Ibezim-Ezeani, M. U., Pat-Okunbor, A. E., Obi. C. 2017. Comparative investigation on fourier transform infrared spectra of unmodified, extract and modified Cola lepidota seed. Journal of Scientific and Engineering Research, 4: 1-6.

Langmuir, I. 1918. The adsorption of gases on plane surfaces of glass, mica, and platinum. Journal of American Chemical Society, 40: 1361-1403.

Jurasovic, J., Cvitkovic, P., Pizent, A., Colak, B., Telišman, S. 2004. Semen quality and reproductive endocrine function with regard to blood cadmium in Croatian male subjects. Biometals, 17: 735-743.

Menke, A., Muntner, P., Silbergeld, E. K., Platz, E. A., Guallar, E. 2009. Cadmium levels in urine and mortality among US adults. Environmental Health Perspectives, 117: 190.

Mohammadi, N., Khani, H., Gupta, V. K., Amereh, E., Agarwal, S. 2011. Adsorption process of methyl orange dye onto mesoporous carbon materialkinetic and thermodynamic studies. Journal of Colloid and Interface Science, 362: 457-462.

Nethaji, S., Sivasamy, A., Mandal, A. B. 2013. Adsorption isotherms, kinetics and mechanism for the adsorption of cationic and anionic dyes onto carbonaceous particles prepared from Juglans regia shell biomass. International Journal of Environmental Science and Technology, 10: 231-242.

Ogbu, J. U., Essien, B. A., Kadurumba, C. H. 2007. Nutritional value of wild Cola spp. (monkey kola) fruits of southern Nigeria. Nigerian Journal of Horticultural Science, 12: 113-117.

Ogbu, J. U., Umeokechukwu, C. E. 2014. Aspects of fruit biology of three wild edible monkey kola species fruits (Cola spp: Malvaceae). Annual Research and Review in Biology, 4: 2007- 2014.

Redlich, O., Peterson, D. L. 1959. A useful adsorption isotherm. Journal of Physical Chemistry, 63: 10241024.

Saleh, T. A., Gupta, V. K. 2014. Processing methods, characteristics and adsorption behavior of tire derived carbons: a review. Adavanced Colloid Interface Science, 211: 93-101.

Saravanan, R., Thirumal, E., Gupta, V. K., Narayanan, V., Stephen, A. 2013. The photo - catalytic activity of $\mathrm{ZnO}$ prepared by simple thermal decomposition method at various temperatures. Journal of Molecular Liquids, 177: 394-401.

Sekar, M., Sakthi, V., Rengaraj, S. 2004. Kinetics and equilibrium adsorption study of lead (II) onto activated carbon prepared from coconut shell. Journal of Colloid and Interface Science, 279: 307-313.

Soco, E., Kalembkiewicz, J. 2016. Comparison of adsorption of $\mathrm{Cd}$ (II) and $\mathrm{Pb}$ (II) ions on pure and chemically modified fly ashes. Chemical and Process Engineering, 37: 215-234.

Temkin, D. 1934. Die gas adsorption under nernstsche warrmesatz. Acta. Physicochima URSS, 1: 36-52.

Vieira, A. P., Santana, S. A. A., Bezerra, C. W. B., Silva, H. A. S., Santos, K. C. A., Melo, J. C. P., Airoldi, C. 2014. High performance maleated lignocellulose epicarp fibers for copper ion removal. Brazilian Journal of Chemical Engineering, 31: 183-193.

Vinod, G. K., Rajeev, J., Arunima, N., Shilpi, A., Meenakshi, S. 2011. Removal of hazardous dyeTartrazine by photo-degradation on titanium dioxide surface. Materials Science and Engineering: $C$, 31: 1062-1067. 